\title{
Skin ulceration around stoma associated with aflibercept
}

\author{
Sho Fujiwara, ${ }^{1}$ Yumiko Chida ${ }^{2}$
}

'Department of Surgery, Iwate Prefectural Chubu Hospital, Kitakami, Japan

${ }^{2}$ Department of Nursing, Iwate Prefectural Chubu Hospital, Kitakami, Japan

\section{Correspondence to}

Dr Sho Fujiwara,

sho.fujiwara@med.tohoku.ac.jp

Accepted 30 August 2019

\section{DESCRIPTION}

A 56-year-old man was diagnosed with rectal cancer, multiple lung and liver metastases, and paraaortic lymph node metastasis. He underwent a sigmoidoscopy and was treated with 10 courses of modified FOLFOX6 chemotherapy plus bevacizumab and three courses of FOLFIRI plus bevacizumab without any adverse skin effects. Because of RECIST progression of the disease with these treatments, the regimen was changed to FOLFIRI plus aflibercept. After two courses of the new regimen, the patient developed a skin ulcer around his stoma (figure 1). This was diagnosed as an adverse effect of aflibercept, and the regimen was changed to FOLFIRI alone. Although the ulcer was improving after 5 weeks, metastasis progressed. Therefore, we initiated FOLFIRI plus ramucirumab treatment.

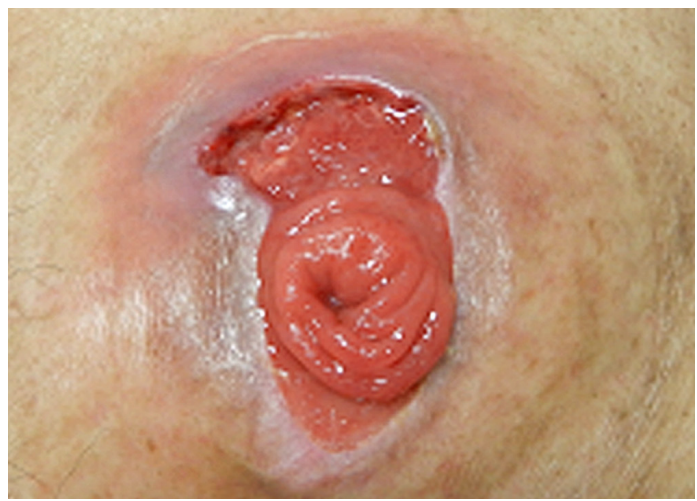

Figure 1 Skin ulceration after using aflibercept.

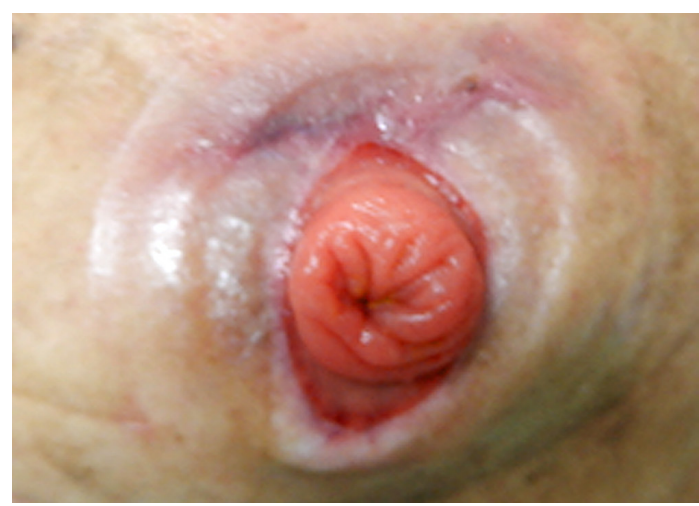

Figure 2 Skin ulceration after changing to ramucirumab.
Skin ulceration did not occur with this regimen, and he was safely treated with effective chemotherapy again (figure 2).

Skin ulceration around a stoma is a rare adverse effect of aflibercept. ${ }^{1}$ Although skin ulcers with bevacizumab have been reported, there has only been one report concerning ulcerations on an abdominal wound scar that was associated with aflibercept. ${ }^{2}$ These agents affect different vascular endothelial growth factor (VEGF) pathways: aflibercept inhibits VEGF-A, VEGF-B and placental growth factor; bevacizumab inhibits VEGF-A; and ramucirumab inhibits VEGF receptor-2 (VEGF-A, VEGF-C and VEGF-D binding). ${ }^{3}$

This may be the first report of skin ulceration around stoma associated with aflibercept. Appropriate care of the stoma and changing the treatment regimen should enable the continuation of effective chemotherapy combined with antiangiogenic agents.

\section{Learning points}

Aflibercept-associated skin ulceration around a stoma is extremely rare.

- Appropriate skin care and changing the regimen to other antiangiogenic agents may enable the safe continuation of effective chemotherapy.

Contributors SF performed operation and treatments. YC cared stoma and skin ulceration as a CN.

Funding The authors have not declared a specific grant for this research from any funding agency in the public, commercial or not-for-profit sectors.

Competing interests None declared.

Patient consent for publication Obtained.

Provenance and peer review Not commissioned; externally peer reviewed.

\section{REFERENCES}

1 Tabernero J, Van Cutsem E, Lakomý R, et al. Aflibercept versus placebo in combination with fluorouracil, leucovorin and irinotecan in the treatment of previously treated metastatic colorectal cancer: Prespecified subgroup analyses from the VELOUR trial. Eur J Cancer 2014;50:320-31.

2 Rivas-Tolosa N, Calomarde L, Bancalari B, et al. Ulcerations on abdominal wound scar associated with aflibercept therapy. J Dermatol 2016:43:1095-6.

3 Clarke JM, Hurwitz HI, Rangwala F. Understanding the mechanisms of action of antiangiogenic agents in metastatic colorectal cancer: A clinician's perspective. Cancer Treat Rev 2014;40:1065-72. 
Copyright 2019 BMJ Publishing Group. All rights reserved. For permission to reuse any of this content visit https://www.bmj.com/company/products-services/rights-and-licensing/permissions/

BMJ Case Report Fellows may re-use this article for personal use and teaching without any further permission.

Become a Fellow of BMJ Case Reports today and you can:

- Submit as many cases as you like

Enjoy fast sympathetic peer review and rapid publication of accepted articles

Access all the published articles

Re-use any of the published material for personal use and teaching without further permission

Customer Service

If you have any further queries about your subscription, please contact our customer services team on +44 (0) 2071111105 or via email at support@bmj.com.

Visit casereports.bmj.com for more articles like this and to become a Fellow 